\title{
A nascente do amor
}

\author{
Geraldo Luiz Borges Hackmann
}

A primeira questão é precisar qual é o sentido de amor que aqui se vai falar. É notório que a palavra amor está desgastada pelo uso que dela é feito. As músicas populares, a literatura, as revistas e as novelas da televisão oferecem uma conceituação muito característica de amor, além do que a compreensão do amor está passando por uma metamorfose no mundo de hoje, caracterizado por uma crescente mentalidade individualista e subjetivista. Esta maneira de ver, muitas vezes, choca e se está afastando diametralmente do conceito cristão de amor. É a isso que se refere o Papa, no número 2 da Encíclica Deus Caritas est, quando toca o problema da linguagem.

$\mathrm{Na}$ realidade, o amor não pode, em si, ser definido, apenas descrito. Pelo que ele representa em relação a Deus e ao próprio ser humano, o amor é um mistério. Mas um mistério que se faz história, porque, no decorrer do tempo, se tem procurado compreender a Deus e ao ser humano a partir do amor, que, para o cristianismo, está presente e agindo na história humana desde a experiência do êxodo até chegar ao seu ponto culminante na encarnação do Filho de Deus (cf. Jo 1,14$)^{1}$.

E o próprio amor tem uma longa trajetória, iniciada desde o advento da pessoa humana no nosso planeta e a acompanha desde então, enquanto acompanha o itinerário do ser humano no mundo. Assim, ele se torna, ao mesmo tempo, reflexão e ato, porquanto toda pessoa ama e quer ser amada.

\footnotetext{
${ }^{1}$ Cf. K. RAHNER, Corso fondamentale sulla fede. Introduzione al concetto di cristianesimo. Roma: Paoline, 1978, p. 279.
} 
Desse modo, ele ocupa um lugar preponderante na vida de todo ser humano. Essa reflexão e esse ato vão assumindo características sempre novas a cada fase da história da humanidade, com suas características e aspectos diferentes na medida em que a humanidade vai construindo a sua história no mundo.

Assim se entende que o amor não é apenas um aspecto particular da vida humana, mas indica a totalidade da existência humana e, como tal, faz parte do pequeno grupo de palavras-chaves sob as quais se intenta esclarecer o todo da existência humana. E, por isso, se entende que ele apareça em todas as religiões. Porém, aqui se fará referência específica a maneira como o cristianismo entende o amor.

Indubitavelmente, o amor é um conceito chave do cristianismo. Ele já se faz presente no Antigo Testamento, como no livro do Deuteronômio (cf. $D t 6,4 \mathrm{ss}$ ), ao narrar a experiência da misericórdia de Deus pelo povo de Israel, que conduziu o povo do Egito até a terra prometida. Contudo, é só no Novo Testamento que ocupa um lugar central, devido a revelação plena do amor de Deus em Jesus Cristo, a ponto de se encontrar nele a compreensão da essência de Deus como amor (cf. 1Jo 4,8.16). E, por isso, Duns Escoto dirá que Deus formaliter est caritas. Talvez se possa compreender o que se quer dizer com essa afirmação, contudo o amor entra no mistério absoluto, que é Deus, e, assim, o amor se torna incompreensível para a inteligência humana. E a afirmação de que Deus nos ama só pode ser compreensível e apreendida em um ato de fé e de esperança, porque o amor de Deus por nós não é simplesmente experimentado como algo natural do mundo, senão o esperado pela fé contra toda a esperança $(R m 4,18)^{2}$.

Neste sentido, amor indica a relação de Deus para com a pessoa humana, e da pessoa humana para com Deus e das pessoas entre si. Essa designação no cristianismo assumiu um caráter tão universal que indica um dado da experiência do mundo. Por essa razão, foge do escopo deste trabalho fazer uma história filológica e fenomenológica do amor, tal como é vivida pelo ser humano em sua experiência cotidiana nas relações com os outros seres humanos em geral ou para com uma pessoa em particular, condicionada pelo corpo e pela história. Também não se pretende fazer uma teologia tendo o amor como idéia nucleadora, a fim de fazer uma "teologia do amor".

\footnotetext{
${ }^{2}$ K. RAHNER, Amor. ID, Sacramentum Mundi, vol 1, Barcelona: Herder, 1976, col. 114-115.

${ }^{3}$ A propósito, ver a exposição que o autor faz de uma teologia como "teologia do amor": O. PESCH, Amor. EICHER, P. Diccionario de conceptos teológicos. Herder: Barcelona, 1989, p. 35-50.
} 
O presente texto inicia por apresentar a concepção de amor no Antigo Testamento, para depois examina-lo a partir da sua novidade, introduzida por Jesus Cristo, concluindo com uma reflexão teológica sobre o amor. A pesquisa bíblica abre a possibilidade de se elaborar uma teologia do amor fundamentada na Sagrada Escritura. É que o transparece na Encíclica Deus Caritas est, do Papa Bento XVI, que contém uma reflexão atualizada sobre o amor, notadamente em sua primeira parte.

\section{1 - A palavra amor nas Escrituras}

A língua hebraica ${ }^{4}$ traduz o conceito de amor com a palavra $a h a b a$, como nas palavras aheba, ahab, ohab, etc. Na tradução grega dos Setenta, quase sempre se recorreu ao termo substantivo feminino agápe e ao verbo agapán. Assim, está evitado sistematicamente o emprego de éros, erán. São muito pouco usados os termos philía, philéin, que aparecem, normalmente, em contextos não religiosos. Assim, o substantivo feminino agápe (com o acento na segunda sílaba) indica o amor a Deus.

Inicialmente convém lembrar que nem sempre o vocábulo amor foi usado no Antigo Testamento, enquanto outras palavras foram empregadas com o mesmo conteúdo indicado pelo amor de Deus. É o caso de uma das profissões de fé mais antigas que proclamavam os gestos salvíficos de Deus vivenciados pelo povo de Israel na experiência do Êxodo e na conquista da terra prometida (cf. Dt 26,5-10), que não fala explicitamente do amor de Deus, mas apresenta de modo claro a misericórdia e a benevolência de Deus para com o povo de Israel, com o sentido de amor de Deus.

Contudo, no Antigo Testamento, a idéia de amor tem um caráter profano ou imanente e outro religioso e teológico. O conceito profano entende o amor como a atração mútua dos sexos. Os profetas Ezequiel, Oséias e Jeremias empregam a palavra ahaba com sentido sexual, para indicar o apetite sexual, a atração mútua dos sexos (cf. Ez 16,37; Os 2,7; 3,1; 4,18; 9,10; Jr $22,20.22 ; 30,14)$. Ehab (Os 3,1) significa o ato sexual, mas inegavelmente em forma eufemística, enquanto indica o amor perseverante de Deus pelo seu povo escolhido e infiel. O Cânticos dos Cânticos indica e reconhece o amor entre homem e mulher e o amor conjugal como um fato natural. $\mathrm{O}$ texto de 8,6 descreve a força da paixão e do amor como uma força positiva. Desse modo, a força erótica se afirma enquanto uma força primordial.

O sentido religioso e teológico põe em relevo o amor misericordioso e redentor de Deus para com Israel. A vida do profeta Oséias mostra de modo

\footnotetext{
${ }^{4}$ Sigo, neste ponto e no próximo, QUELL, G. e STAUFFER, E. Agapán. G. KITTEL e G. FRIEDRICH, Grande Lessico del Nuovo Testamento. Brescia: Paideia, 1965, vol. 1, col. 57-146.
} 
dramático o amor de Deus pelo povo de Israel. Ele é testemunha de um amor intensamente pessoal de Deus, descrito como um marido que não quer abandonar seu povo prostituto $(O s$ 1,2-3,5). No dêutero-Isaías, Deus é descrito como uma mulher que grita pelas dores de parto $($ Is 42,14$)$ ou como uma mulher que deu a luz e carrega Israel (Is 46,3-4; 49,15). Os profetas, assim, são obrigados a descrever Deus como pai, mãe ou esposo (cf. Dt 32,6). E eles não podem agir de outra forma, de tal modo calou neles a experiência de um Deus que ama, salva e é ternamente afeiçoado a Israel.

Assim, a palavra ahaba indica relações amorosas, não necessariamente reduzíveis de modo algum à sexualidade, pois nelas está ausente a paixão libidinosa, dando lugar ao afeto do pai e da mãe e as relações de consangüinidade e de amizade como as relações sociais e jurídicas. Contudo, aqui não há diferenciação entre éros e ágape, embora parece haver em $1 S m$ 1,26.

$\mathrm{O}$ conceito religioso de amor indica o amor de Deus pelas criaturas, e é, freqüentemente, expresso pelo uso restrito da compaixão pelos sofredores e necessitados. E, por isso, usado para indicar o amor de Deus para com a criatura. Desse modo, o termo rahûm, misericordioso, é reservado exclusivamente para Deus. Nos Setenta, este termo exprime o amor fundamental como sentimento espontâneo, que leva a fazer-se dom de si mesmo à pessoa amada ou, no caso de coisa, a posse do objeto que suscita desejo ou a realização da ação na qual se encontra o prazer.

A explicação para tal fenômeno é que as características comuns entre ambos devem ter dominado de tal forma a mente dos autores do Antigo Testamento que eles não achavam necessário distinguir. É o caso, por exemplo, do afeto de Saul para com Davi, como se encontra em $1 S m$ 16,21, onde a palavra me'od indica a força que se manifesta nele. O mesmo de Jônatas para com Davi. Em ISm 18,1.3, a expressão “como a si mesmo" é empregada para afirmar que Jônatas se identifica de tal forma com Davi como com a sua própria alma, indicando, assim, a intensidade do sentimento.

O Antigo Testamento também se refere ao amor para com o próximo. Em $L v$ 19,18, a palavra "rea" indica o próximo, que, embora seja uma linguagem jurídica, a palavra ahaba, sendo determinada pelo sentimento, se subtrai a qualquer prescrição legal. Por isso, pode designar também o inimigo. Portanto, só falar do amor de uma pessoa para outra pertence ao fundamento vital e instintivo do conceito, o que estará sempre presente no linguajar religioso. É o que se pode denominar de o caráter pessoal do amor. Desse modo, o amor é uma força espiritual inexplicável, conatural à pessoa. É como diz o texto de Deuteronômio: "amar com todo o teu coração, com toda a tua alma e com toda a tua força" $($ Dt 6,$5 ; 13,4)$. 
No judaísmo, a palavra ahaba exprime ora a paixão entre homem e mulher, ora a fidelidade desinteressada ao amigo ( $1 \mathrm{Sm} 20$ ), ora a segura observação da justiça, como em $S l$ 45,8. Desse modo, o amor de Deus por Israel não é um simples impulso, mas um ato de vontade, conforme mostra $D t$ 7,13 . O mesmo vale para o amor para Deus e o próximo, como ensina $D t 6,5$ e $L v 19,18$. Essa compreensão da lei do amor imposta ao israelita não é um êxtase ou enlevo sensível, mas uma verdadeira ação.

O amor compreendido desse modo não se confunde com o erotismo religioso, presente de forma clara nos ritos da fecundidade do circundante mundo mediterrâneo e da religião grega, como já mostrava o Papa no número 4 da Encíclica. Daí que a religião do Antigo Testamento se diferencia das religiões circunvizinhas. A característica essencial do ahaba israelita, isto é, do amor, é o seu exclusivismo. O eros grego é um amor cósmico, vasto, indiscriminado; o amor no Antigo Testamento é um amor cioso, que escolhe seu objeto entre milhares de outros, o domina com toda a força da paixão e da vontade e não admite infringir a fidelidade. Deus pôs muitos povos no mundo, mas a um só ama, que é o seu povo eleito, que goza de seu amor e com o qual celebra uma aliança e estabelece um elo nupcial, como demonstra os primeiros capítulos de Oséias. Contudo, ele pune a culpa da infidelidade, mas não deixa de ser misericordioso, como demonstra Ex 20,2ss. O amor regula as relações entre Deus e o homem, mas especialmente entre Deus e o seu povo. Deus é o enamorado do Cântico dos Cânticos.

O mesmo exclusivismo se encontra no amor ao próximo. É um amor que faz distinção, escolhe, prefere; não é um amor que abraça as multidões, mas ama a família, o seu povo e o estrangeiro enquanto faz parte da sua casa e do seu povo (Ex 20,10; 22,20). Também o inimigo, quando ele necessita, deve ser tratado com benevolência ( $E x$ 23,4ss). Por isso, um tema predileto do cristianismo é o "amor ao próximo". Não é só um mandamento de Deus, mas, como amor para Deus, está radicado nele mesmo. O ódio vem do diabo, o amor vem de Deus. $\mathrm{O}$ ódio conduz à morte, o amor à generosidade e à salvação do homem.

O grego pré-bíblico tem diversos verbos que significam "amor", que são os seguintes: a) eran: indica o amor passional, o desejo de possuir o outro; b) filein: indica a inclinação, o afeto pressuroso dos deuses para com os homens, também do amigo para com o amigo; c) agapán: indica o sentimento de estar contente por alguma coisa, freqüentemente acolher, saudar, tratar com as honras devidas, mirar alguma coisa, ver com bons olhos alguém ou alguma coisa ${ }^{5}$.

${ }^{5}$ G. QUELL E E. STAUFFER, Agapán. G. KITTEL e G. FRIEDRICH, Grande Lessico del Nuovo Testamento. Paideia: Brescia, 1965, vol. I, col. 98. 
Desse modo, tanto a tradução grega do Antigo Testamento quanto o Novo Testamento irão preferir a mesma palavra para falar do amor, a agápe. Sempre tem significado profano e um grande significado religioso. Daí que falar de amor pelas coisas ou ações pertence a uma linguagem descolorida e figurada de amor.

\section{2 - O amor segundo o ensinamento de Jesus}

A decisão dos Setenta de traduzir a palavra hebraica correspondente por ágape levou os autores do Novo Testamento a preferir as palavras agápe e agapán, menos freqüentes no grego profano ou clássico. O conjunto dos livros do Novo Testamento usa 141 vezes o verbo agapán, 117 vezes o substantivo agápe e 61 vezes o adjetivo agapetós. É com este sentido que João irá afirmar que "Deus é amor", como se encontra em $1 J_{o}$ 4,8-16. São Paulo, no hino à caridade, a entende da mesma forma quando afirma "se eu não tivesse o amor" (1Cor 13,2). A palavra também passa a indicar o amor ao próximo, assim como para com o inimigo.

Assim, pois, o vocábulo agápe aparece como o termo particular pelo qual o Espírito Santo se serviu para o amor que tem sua origem em Deus. As palavras derivadas de philéin são usadas com certa freqüência, mas apenas três vezes como sinônimas de agápe. Os termos eros e erán são ignoradas pela Sagrada Escritura, embora muito em voga na literatura grega.

\section{$2.1-$ A nova lei}

Jesus ensinou uma nova $\mathrm{lei}^{6}$, resumindo em dois preceitos o sentido da lei antiga e da lei nova: amar a Deus e amar ao próximo (Mc 12,28ss; $M t$ $22,40)$. Essas são palavras sublinhadas mais vezes também explicitamente pelos rabinos. Contudo, o mandamento do amor de Jesus $(M t 5,44 ; 7,12)$ se distingue do famoso preceito de $\mathrm{Hillel}^{7}$ somente pela sua formulação positiva. Contudo, Jesus, mesmo seguindo conscientemente a tradição de seu povo, torna o mandamento do amor resumo de todos os outros mandamentos e o faz critério de toda a lei e de toda a justiça. Eis a sua nova lei.

Também para Jesus o amor é vontade e é ação. Mas ele quer que o amor esteja voltado para Deus e somente a Deus com uma devoção ilimitada

\footnotetext{
${ }^{6}$ G. QUELL E E. STAUFFER, Agapán. G. KITTEL e G. FRIEDRICH, Grande Lessico del Nuovo Testamento. Paideia: Brescia, 1965, vol. I, col. 57-146.

${ }^{7}$ Hillel resume todos dos mandamentos em um só preceito: "Não fazer ao próximo o que é odioso para ti; esta é toda a Lei. O resto são somente precisações" (Shab 31,a; Lev 19,18).
} 
de tal forma que seus interlocutores se espantavam ao ouvi-lo. Amar a Deus está sob um radical ou-ou, como transparece em $M t 22,37$ e $M t 6,24 \mathrm{ss}$. Amar a Deus significa viver como o servo para o seu patrão ( $L c 17,7 \mathrm{ss})$, obedecer fiel e humildemente aos seus preceitos, submeter-se a sua soberania e pôr acima de tudo a realização de seu reino (cf. $M t$ 6,33). Mas também significa fundar toda a sua existência em Deus, segui-lo com confiança ilimitada, colocar nele toda cura e responsabilidade última, viver como ele quer. Ainda mais, significa desprezar o respeito humano e superar cada obstáculo (cf. $M t$ 5,29 ss) e romper todos os elos que não são com Deus.

Para Jesus, cada pessoa deve opor-se radicalmente contra dois poderes, caso queira amar a Deus: a mamona ${ }^{8}$ e a ambição. Quem quer acumular riquezas é alguém de pouca fé, um pagão e não tem esperança de entrar no Reino de Deus (Mt 6,24b e 30ss). É o que retratam as ameaças feitas por Jesus aos fariseus (cf. $M t$ 23; Lc 11,43). Em $M t$ 23,6, o verbo gostar significa amar, a ser entendido como "ama o trabalho de cada dia". A busca da honra mal se concilia com o amor de Deus. Por isso, Jesus ensina a humildade e a servir ao próximo (Mt 6,19-21.24; Jo 13,16).

Mas ainda há um terceiro perigo, que é a perseguição. Jesus sabe que a hostilidade, as amarguras, os escárnios e os sofrimentos que se abaterão sobre seus discípulos serão a prova de fogo para a fidelidade deles (cf. $M t$ $10,17 \mathrm{ss} ; 5,10 \mathrm{ss}$ ). Quando chegar a última hora, a decisiva, deverá vencer a paixão ardente por Deus, a paixão dolorosa de uma pequena porção que permanece fiel malgrado todas as adversidades. Este é o amor pregado por Jesus.

O amor a Deus é o grande e fundamental preceito de Jesus (Mt 22,3738). Contudo, ele não é um preceito abstrato nem vago e, por isso, se traduz também no amar o próximo (Mt 22,39). Por isso, Jesus ensina a amar ao próximo como a si mesmo. Mas abole para sempre a estreiteza do "amor ao próximo" limitado ao co-nacional e o concentra nos humildes e em suas necessidades. Ele transforma uma controversa questão jurídica em uma questão do coração, de tal forma categórica a excluir reservas ou exceções. De uma prescrição legal passa a ser um preceito interno, atingindo a consciência e a vontade da pessoa, não implicando apenas suas atitudes externas, como queriam os fariseus. Daí ele reprovar a atitude deles, chamando-os de "sepulcros caiados" (Mt 23,27) e guias cegos $(M t$ 23,24).

\footnotetext{
${ }^{8}$ Ver o significado de mamona em J. DE FRAINE, Mâmon. A. VAN DE BORN, Dicionário enciclopédico da Bíblia. Petrópolis: Vozes, 1977, col. 929.
} 
A "regra de ouro" (Mt 7,12; Lc 6,31) poderia ser entendida de forma filantrópica e assim o é na ética de Aristóteles até Kant ${ }^{9}$. Mas a parábola do Bom samaritano (Lc 10,29-36) exclui essa interpretação. Jesus não responde à pergunta do fariseu com uma classificação sistemática das várias categorias de homem, do mais distante ao mais próximo. Ele inverte a antiga hierarquia concêntrica baseada no "eu", embora conservando o conceito de "próximo", para uma nova hierarquia na qual o "tu" está no centro. Não é rígida e esquemática, válida para todas as pessoas e circunstâncias, mas se realiza em torno do que sofre, seja quem for e quando for. No samaritano está viva a lei do coração, sem nada de sentimental, porque ele faz o que pede a circunstância presente e se preocupa com o futuro imediato do samaritano agredido, não fazendo nada a mais nem a menos. Ao agir desta forma, ele foge do mero sentimentalismo, transformando o amor em vontade e ação.

Ao formular o mandamento de amar aos inimigos, Jesus rompe deliberada e conscientemente com a tradição judaica ( $M t$ 5,43ss e $L c$ 6,32ss), particularmente quando diz "Eu, porém, vos digo" (Mt 5,22.44). É o mandamento de uma nova época $(M t 5,21.43)$, que leva a superar a mera retribuição (cf. $M t 5,46 \mathrm{ss}$ ). Daí que o seguidor de Jesus irá amar sem esperar recompensa, enfrentará as adversidades e as hostilidades do mundo sem opor resistência e com espírito de sacrifício ( $L c$ 6,28). Ele irá agir de modo contrário ao mundo, pois beneficiará quem o odeia, recompensará a maldição com bênçãos e rezará por quem lhe persegue $(L c 6,27 \mathrm{ss} ; M t 5,44)$.

\section{2 - A nova realidade}

Jesus não só formula um novo preceito, mas cria uma nova realidade. Ele revela a misericórdia de Deus não como atitude constante e habitual do ser supremo, mas como fato inaudito, possível só para Deus, mas transforma radicalmente a posição do homem. Jesus perdoa os pecados e faz, com isso, nascer um amor todo novo e irresistível. Neste sentido, Jesus perdoa a pecadora, porque muito ama (cf. $L c$ 7,47). Esse amor provoca o início de uma nova vida, nascida do amor de Deus, que suscita refazer os valores e a forma de viver até então (cf. $M t$ 24,12).

O perdão dá uma nova ordem à humanidade, que supera todas as estruturas antigas e cria novas possibilidades e novas tarefas. A nova relação entre Deus e a pessoa humana supõe uma nova relação entre as pessoas,

\footnotetext{
${ }^{9}$ A propósito, ver leitura filosófica de amor em M. C. NUSSBAUM, Love. E. CRAIG, Routlege Enciclopedy of Philosophy. London and New York: Routlege, 1998, v. 5, p. 842-846.
} 
firmada na misericórdia: "Sede misericordiosos como o vosso Pai é misericordioso" (Lc 6,36).

Por isso, o amor de Deus se revela à humanidade como um amor misericordioso, feito de perdão. Porém, Jesus conhece outro amor, o de preferência. Esse "amor preferencial", Deus Pai tem para com aquele que ele escolheu para uma missão única e incomparável, como fica claro na parábola dos vinhateiros homicidas (cf. $L c$ 12,1-11; Mc 12,5). Assim, a vocação do filho unigênito é ir até a morte, como os profetas, pois ele é o "mártir supremo" (cf. Mt 12,18; 1Jo 3,16).

A novidade do amor cristão está, em primeiro lugar, em ser um amor eterno do Pai a seu Filho Unigênito e o amor atemporal do Filho para com seus seguidores e, segundo, pela riqueza do conteúdo que confere aos que o aceitam e vivem. Não é um amor puramente humano, porque Jesus acrescenta o "assim como eu vos amei" (Jo 13,34; 1Jo 4,19-21).

Com Ceslas Spicq, pode-se apontar as seguintes razões para a novidade do amor segundo Jesus Cristo: a) na Primeira Aliança, o amor era um preceito secundário, enquanto na Nova Aliança, ele está equiparado ao amor a Deus; b) o amor ao próximo é determinado não mais pelo sangue, como em $L v$ 19,18, mas pela fé; c) no sermão da montanha, Jesus prescreveu amar também aos inimigos; d) agora todos devem amor como Cristo ama, demonstrando, assim, o enraizamento cristológico do mandamento novo; e) recapitula a lei e os profetas, como afirma Paulo em $R m$ 13,8-10; f) cria um sentido novo para os atos e atitudes das pessoas, enquanto o amor se realiza na cruz (cf. $\left.1 J_{o} 3,16\right)^{10}$.

\section{3 - A reflexão teológica}

Após a reflexão bíblica da palavra amor e a análise da novidade do mandamento novo de Jesus Cristo, segue uma abordagem mais sistemática do amor cristão, apesar de prescindir sobre uma abordagem bíblica mais ampla $^{11}$ e da tradição patrística ${ }^{12}$.

\footnotetext{
${ }^{10}$ C. SPICQ, O amor de Deus. São Paulo: Paulinas, 1981, p. 46-47. Apud B. KLOPPENBURG, B. Ágape. O amor cristão. São Paulo: Loyola, 1998, p. 38-40.

${ }^{11}$ A título de exemplo, pode-se trazer alguns elementos do apóstolo Paulo. O apóstolo Paulo entende que o amor de Deus implica em uma eleição, na qual se manifesta a soberaneidade de Deus, tanto na eleição quanto na condenação (cf. $R m$ 9,13.25), recorrendo as expressões "amados de Deus", "eleitos de Deus", "santos e amados" $(R m$ 1,7; Cl 3,12). O conceito do amor de Deus é claro: é a vontade soberana de Deus que se volta ao mundo das pessoas humanas e aí opera a salvação. Este ato de amor corresponde a uma finalidade que Deus tem desde o princípio. Neste sentido, Deus pensou um povo livre da escravidão da lei e livre no Espírito $(G l 5,2-6,10)$, que é visto como espírito de amor $(G l 5,22)$.
} 


\section{a) A essência do amor}

A teologia do amor precisa investigar qual é a essência do amor. Muitos problemas advêm do fato de não se saber com clareza qual é essa essência. Sem dúvida, que o amor é uma força fundamental presente na pessoa humana, pois representa a realização de sua natureza e de sua essência. Não se pode negar que ele está ligado a sentimento e ao ânimo, ao desejo e a nostalgia. Contudo, a análise mais profunda mostra que o amor não é um mero afeto, ou seja, uma excitação do sentimento, causada por algo externo ou mesmo interior da própria pessoa. Também não é uma simples tendência instintiva ou desejo.

Mais profundamente, a essência do amor é uma inclinação, que quer levar à união com o amado. Uma inclinação que brota do centro mesmo do ser, e de que todos os outros aspectos são conseqüências, como o impulso sexual, o ímpeto, a afirmação do valor da pessoa amada, ou uma decisão pessoal. Contudo, essa inclinação não pode ser compreendida de forma abstrata ou metafórica, ou como algo meramente sentimental, porque deve ser

No capítulo oitavo da carta aos Romanos, Paulo afirma a liberdade de uma vez por todas. O desígnio de Deus, que é sua iniciativa, a sua escolha e o seu chamado tem um valor absoluto. Daí decorre tudo o que se pode chamar de agápe. O amor de Deus se irradia sobre o cristão e, nele, se completa a aliança que Deus fez com seus eleitos, tornando-os filhos de Deus (cf. $R m$ $8,2.14 .18 .28-30.35)$.

O escopo do amor de Deus é colocar a sua vida, feita de amor e liberdade, ao serviço do próximo (cf. Gl 5,13ss). Do amor ao próximo se fala em $R m$ 13,8ss (cf. 1Ts 3,12). A agápe está sob a marca do télos. Esta é a grande verdade de 1 Cor 13. Por isso, o amor é dom celeste maior que todo carisma. Não só está no centro da tríade "fé, esperança e amor", mas é superior à fé e à esperança. As duas pertencem ao transitório, mas o amor não terminará. A agápe está sempre no centro (cf. $1 T s$ 1,3; 5,$8 ; \mathrm{Cl} 1,14)$.

12 Também a título de exemplo, segue alguns aspectos sobre Santo Agostinho. Com Agostinho, o tema "amor" chega a um novo nível de grande transcendência histórica, porque na disputa com Pelágio ele entende a "graça" como, "contrapeso" (pondus) interno contra o pecado. Daí que a graça tem de ser formalmente idêntica com o amor de Deus, já que o pecado é amor próprio, egoísmo como contrário exato da agápe bíblico.

Agostinho elaborou a síntese entre a doutrina grega (neoplatónica) e a cristão do amor. Ele distingue entre o amor sui, a concupiscência (cupiditas), e o amor Dei, que é a caridade. Também que só pode ser amado por si mesmo. E amor para consigo mesmo e para com as criaturas deve ser ordenado para Deus. Assim, a caritas considera Deus como o sumo bem, como fons nostrae beatitudinis, de modo que no amar a Deus o amor para conosco encontra a sua verdadeira realização.

Ele considera que toda a caritas provém de Deus como graça, para retornar depois para a sua fonte através do amor de Deus e ao próximo. Esse retorno não é, como o eros, só fruto das próprias forças, mas só é possível graças à força do amor proveniente de Deus. O amor ao próximo é sacramental, pois funda a Igreja sob o sacrifício da Eucaristia, ou seja, sobre o amor de Cristo que se doa e, como amor fraterno, a constrói. 
entendida como uma relação fundamental para com os outros, como "amor de ser", nascido junto aos outros seres e que se fundamenta sobre a unidade transcendental (por isso, não se restringe ao instinto sexual ou emocional). Assim, o amor como inclinação diz uma predisposição para o outro e certa determinação do comportamento para com o outro, seja interior - espontaneidade, a própria iniciativa, seja exterior - a atração exercida pelo amado.

Os dois aspectos estão presentes, gerando certa ambivalência no amor. Essa se manifesta não só na sua reciprocidade, que dá e recebe, mas também no próprio ato de amar, quando a pessoa é considerada apenas pelos seus valores, que podem existir ou não, ao criar valores só porque aquela pessoa é amada.

Contudo, o verdadeiro amor, o pessoal, é essencialmente determinado pelo interior e, assim, espontâneo, mesmo que isso não exclua uma relação secundária ao bem presente no outro e também em relação para com a própria felicidade. Assim, esse amor pessoal pode prescindir de um bem concreto para si e para outros, como se dá no caso do éros. $\mathrm{O}$ amor assim entendido se volta para o ser do outro, não para o seu bem, portanto, para o "tu".

Esse amor supõe uma condição prévia, que é a dignidade da pessoa, isto é, a capacidade de se tornar digno de ser amado. Se fosse incapaz dessa dignidade, seria também incapaz de ser amado. Porém, essa dignidade não se funda pelo valor efetivo ou dignidade do outro, mas de seu próprio ser individual como pessoa humana. É onde a pessoa é chamada responsavelmente por Deus a sua determinação individual.

Assim, o amor provém do mais profundo da pessoa e de seu centro, ou seja, de seu coração. É aí que se unem conhecer, querer e sentir, gerando a unidade da pessoa. É por essa razão que o amor é ato total da pessoa, que lhe exige todas as forças e as leva a sua plenitude. O protagonista é a pessoa integral, como sua força fundamental. É assim que o amor pode doar-se sem se perder e pode alcançar a si mesmo, estabelecendo uma união tal em que a dignidade do que ama e do que é amado se realizam plenamente. Essa reciprocidade faz fugir do egoísmo, porquanto se realiza no nível do ser e não está mais sujeito aos humores e necessidades concretas.

\section{b) O amor de Deus}

Daí que o amor puramente humano só pode realizar-se no amor de Deus, pois a pessoa está marcada pelo pecado, o que a liga o seu "eu" aos sentidos e aos instintos. É por isso que o verdadeiro amor pessoal só é possível como agápe, como participação no amor divino e como cooperação com ele, através do qual Deus mesmo realiza o seu ser. Por isso, como "amor pneumático", enquanto inclinação produzida no coração da pessoa pelo Es- 
pírito divino, ele se distingue de todas as outras maneiras de amar. O verdadeiro amor só pode se realizar plenamente através de Jesus Cristo, por obra do Espírito Santo. É abertura para o outro da existência de toda a pessoa humana, fruto da necessidade do ser humano. Daí se dirige para Deus, onde se funda e encontra a sua realização plena. Por isso, a agápe é visto como um sinal específico da realidade cristã.

A agápe é um dom de Deus, que se utiliza do amor natural para se realizar, libertando-o de seu aprisionamento do instinto e do desejo, e levando a pessoa a sua realização plena. Como virtude, ele torna possível o verdadeiro desenvolvimento do ser da pessoa, cooperando com o amor eterno de Deus. E, assim, aparece como centro da história da salvação. E a pessoa poderá realizá-lo através da participação na morte e na ressurreição de Jesus Cristo, que a transforma e a capacita para uma mudança radical em sua realização pessoal.

Para Deus, a agápe pode se dar incondicionalmente, sem relação alguma para com o próprio bem-estar e também sem temer de faltar ao seu destino. Deus pode amá-Lo só por si mesmo, pois a agápe se realiza não na esfera da tendência da concupiscência, mas no nível mais profundo e livre do ser. A agápe é, pois, essencialmente doação e realização de si ao mesmo tempo. Nele se harmonizam o amor de Deus, ao próximo e a si mesmo. $\mathrm{Na}$ sua liberdade ontológica e pessoal, ele é a plenitude, o verdadeiro pleroma: a mais profunda unidade, embora ficando salvas a independência e a natureza específicas de quem ama.

Daí se compreende porque a essência divina se manifesta e age como agápe e se explique a Trindade das pessoas divinas. O amor do Pai, que está na base de todo ser, gera o Filho como palavra de amor da mesma natureza, e ambas se unem de modo perfeito na "expiração" do Espírito Santo, o qual não é, como se afirma em geral, o amor personificado (que se faz pessoa) no interior da divindade, mas é o amor unificante do Pai e do Filho.

Daí, também, se compreende porque a agápe seja o verdadeiro motivo do desígnio eterno de Deus, o "mistério de sua vontade" (Ef 1,9s), e represente a força motriz e o princípio informador de todos os acontecimentos do mundo, da história da criação e da história da salvação. Enquanto realização do "mistério de Cristo" (Ef 3,4), sobretudo porque o pecado original - como todo o pecado - é um trair a própria destinação pessoal, é, assim, é um ultraje ao amor, que gratuitamente nos elegeu e nobilitou. À luz da agápe se entende a necessidade da salvação, ou seja, a razão íntima em que se realiza a nossa redenção por meio de Jesus Cristo. Como a agápe divino não obriga, mas age respeitando a liberdade humana, o amor de Deus se inseriu na histó- 
ria humana, por meio da encarnação, vencendo o pecado e abrindo o caminho ao santuário $(H b 6,20)$ como precursor.

\section{c) Unidade entre o amor a Deus e o amor ao próximo}

O ponto culminante da história da salvação e a última garantia da unidade entre o amor de Deus e o amor ao próximo se encontra em Jesus Cristo, em sua unidade de Deus e homem, através da encarnação (cf. Jo 1,14). Nele, o amor do Pai se faz presente, como um amor pessoal, e, assim, se abre a todas as pessoas. Nele, a resposta da pessoa, finita e pecadora, encontra seu fundamento e garantia como futuro esperado, enquanto o amor realiza seu caráter incondicional pela graça de Deus. Jesus quer que o amor para com ele $(J o$ 8,42; 14,15.21.23.28), e nele o amor do Pai e ao Filho, se estenda a todos os que amam o Filho $\left(J_{o} 14,21.23 ; 17,23.26\right)$ e "permaneçam em seu amor" ( $\left.J_{o} 15,9 \mathrm{~s} ; 1 J_{o} 4,7\right)$, e, assim, sejam salvos.

O Vaticano II descreve o "grande amor de Deus", tanto a partir do Antigo Testamento quando do Novo Testamento, que fala conosco como a amigos e convida a entrar em comunhão com ele (Dei Verbum 2). E essa autocomunicação de Deus é para a nossa salvação, por isso Deus Pai é a fonte do amor, a fontalis amor (cf. Ad Gentes 2). O ponto culminante da autocomunicação de Deus se dá com Jesus Cristo, através dos eventos de sua vida, morte e ressurreição. Na Encíclica Redemptor Hominis, o Papa João Paulo II afirma que a "revelação do amor de Deus" é também "descrita como misericórdia", pois "na história humana esta revelação do amor de Deus e da misericórdia assumiu uma forma e um nome, que é Jesus Cristo" (Redemptor Hominis 9).

O mesmo se encontra em outra Encíclica do mesmo Papa, a Dives in Misericórdia. Jesus é a revelação viva do amor de Deus. Ele é a presença visível, tangível e credível do amor de Deus, selado por meio de sua morte e ressurreição, ponto culminante da revelação do amor de Deus para com a humanidade. A ressurreição mostra que o amor é mais forte do que a morte (Dives in Misericordia 8). Assim, o coração desta comunicação divina revelada em Cristo foi formulada de modo clássico na expressão "Deus é amor" (1Jo 4,8.16).

A Encílica Deus caritas est, de Bento XVI, aqui em estudo, explicita de forma magistral a compreensão cristã do amor. Jesus Cristo é o "amor encarnado do Pai", no qual a autocomunicação do Pai chega ao seu ponto culminante. Jesus mesmo deu a sua vida pelo ser humana, ovelha perdida, pela qual morreu na cruz e realizou a obra da redenção. Como afirma Bento XVI, com "o olhar fixo no lado trespassado de Cristo, de que fala João (cf. 19,37)", é que se pode contemplar essa verdade (cf. Deus Caritas est 12). E 
"Jesus deu a este ato de oferta uma presença duradoura por meio da instituição da Eucaristia durante a Última Ceia" (id, 13).

Assim, entre muitas possibilidades de estudar o mistério pascal de Cristo, talvez que o amor lhe dá uma chave mais apropriada. A ressurreição de Jesus Cristo se transforma na real e definitiva revelação do amor de Deus pela criatura, obra de suas mãos. João, a partir do capítulo 11 de seu Evangelho, quando se aproxima o mistério pascal de Cristo, começa a introduzir, sempre com mais força, a linguagem do amor. A última ceia e o discurso de adeus de Jesus começam $\left(J_{o} 13,1\right)$ e se concluem $(J o$ 17,26) com esta linguagem. De fato, a oração final de Jesus, que interpreta o centro e o objetivo de sua morte e ressurreição, se conclui com a pergunta do Pai em favor dos discípulos: "a fim de que o amor com que me amaste esteja neles e eu neles" (Jo 17,26).

Em tempos de relativismo, onde impera o subjetivismo e o individualismo, é preciso advogar a unidade entre o amor a Deus e ao próximo, também ao inimigo. Para assim se superar um amor egoísta ou incapaz de chegar a ser verdadeiramente agápe, e ficar apenas no éros ou na filia. O amordoação é fundamental para a maturidade afetiva. Por essa razão, será necessário recuperar o caráter dialógico do amor, como palavra e resposta. Como palavra de Deus e resposta do ser humano; ou como palavra de uma pessoa e resposta de outra pessoa, na relação dialógica entre o "eu" e o "tu".

\section{d) A Igreja como comunidade de amor}

Ao ressurgir dos mortos, Jesus funda a sua comunidade de amor, a Igreja, que será descrita com a imagem da esposa (Ef 5,21-33; Ap 21,2-9). Durante a sua vida terrena, Jesus foi o sinal visível do Pai, como ele diz a Filipe: "Quem me vê, vê o Pai" (Jo 14,9). Após a sua morte e ressurreição, Jesus não pode ser mais visto de forma imediata, por isso, a sua comunidade torna-se o sinal vivo de sua vontade de salvar a todos em todo tempo e lugar. É justamente por isso que o Vaticano II afirma a Igreja como "sacramento de salvação" (Lumen Gentium 1; 49). A Igreja, comunidade de amor, vive na espera da última vinda do Senhor Jesus $(T t 2,13)$, quando a sua glória será plenamente revelada $(1 P d 4,13)$.

Por isso, a Igreja é uma comunidade da agápe (cf. Ef 4,15s) e essencialmente comunhão com a morte e a ressurreição do Senhor. Por meio do sacramento, todos são inseridos na morte e ressurreição do Senhor, de forma real e eficaz, participando de seu mistério pascal redentor. Daí que a agápe é salvação pessoal e comunitária, verdadeira e própria, e se relaciona com a graça santificante. Assim acontece a justificação de toda a pessoa que se 
regenera pelo Batismo. Por isso, todas as virtudes humanas e a vida moral são informadas pela agápe, como um movimento de amor que parte dele e que volta para ele. "Se 'caminhamos na agápe' que é a existencial (e moral) cooperação com o amor de Cristo, que se imola ( $E f 5,21)$, ele mesmo tomará sempre mais 'forma' $(\mathrm{Gl} 4,19)$ em nós, de modo que no homem nos tornaremos nele sempre mais semelhantes a Deus"13.

É na participação da Igreja que acontece a salvação. Por isso, a salvação e a justificação são concebidas no cristianismo como amor. Ambas se dão no amor e não podem ser compreendidas separadas dele. Por isso, as declarações decisivas do Magistério extraordinário sobre o amor se dão no contexto da doutrina sobre a justificação, na sexta sessão do Concílio de Trento. É fundamental a declaração de que a posse da justificação está inseparavelmente unida à posse da virtude da caridade $(D S 1530 ; 1561)$ e que o livre processo da justificação do adulto só chega a seu ponto culminante e a sua plena essência no ato da caridade $(D S 1530 \text { ss; } 1559 ; 1567)^{14}$. Assim, a fé e a esperança, sem prejuízo de sua própria tendência para aperfeiçoar-se na caridade, são atos cuja essência específica não implica a plena união da pessoa pela graça com Deus $(D S 1532 ; 1559 ; 2625)$. Contudo, essa união fica reta e inteiramente expressa com a palavra caridade.

O lugar das faculdades da pessoa humana é universalmente simbolizado pelo coração. Aí é o lugar da agápe. Mateus diz para amar a Deus de todo o coração (cf. $M t$ 22,37). Paulo afirma que o amor de Deus foi derramado em nossos corações (cf. $R m$ 5,5). Diante disso, é preciso formar o coração humano, para que ele possa conhecer, acolher e corresponder ao amor de Deus presente em cada coração humano. E isso implica no esforço da vontade e da inteligência de cada pessoa.

\section{e) Relação com a fé e a esperança}

$\mathrm{O}$ amor tem uma relação com a esperança, pois, afinal, são duas virtudes teologais. A esperança se relaciona com o amor a partir da característica dialógica do amor, enquanto este sempre está a espera da resposta do outro, enquanto resposta livre e pessoal. Mesmo como resposta dada, ela é sempre livre e permanece na dependência dessa liberdade daquele que responde, porque não depende de um cálculo prévio, pois o outro é um sujeito livre, como demonstra o hino à caridade (cf. 1Cor 13,1-13). O mesmo hino mos-

\footnotetext{
${ }^{13}$ W. WARNACH, Amor. FRIES, H. Dicionário de Teologia. Conceitos fundamentais da Teologia atual. São Paulo: Loyola, 1970, p. 90.

${ }^{14}$ Isso continua de pé mesmo quando se admite que a graça da justificação possa ser infundida no sacramento antes do ato da caridade em base a mera atrição, em certas circunstâncias, só mais tarde se atualiza em ato de caridade.
} 
tra, ainda, a função mediadora entre a fé e a caridade exercida pela esperança, afirmando, contudo, a temporalidade da fé e da esperança, pois a caridade é a maior das três virtudes teologais ${ }^{15}$.

\section{f) Como conclusão}

Concluindo, a Encíclica de Bento XVI aborda um tema central do cristianismo. Talvez seja da intenção do Papa chamar a atenção ao que é essencial e fazer voltar à prática o que é fundamental, como faziam os primeiros cristãos, como descreve os Atos dos Apóstolos a vida dos primeiros cristãos, porque, pelo amor de Deus, eles eram "um só coração e uma só alma" (At 4,32) e "o Senhor acrescentava cada dia ao seu número os que seriam salvos" $($ At 2,47$)$. O amor aponta para as relações intra-trinitárias, e, desse modo, serve de modelo para as relações interpessoais, porquanto o amor cristão constrói novas relações livres e responsáveis.

Neste sentido, toda a vida de uma pessoa, desde sua vida espiritual até a moral, é "informada" pela ágape, provocando um movimento de amor, que parte de Deus e atinge a pessoa mesma e retornado para Ele, pois a origem e o fim é o amor de Deus. É como descreve o livro do Apocalipse: "Eu sou o Alfa e o Ômega, diz o Senhor Deus" (Ap 1,8).

Sem dúvida, uma teologia do amor atualizada colocaria o cristianismo em seu centro unificador e daria à Teologia um foco novo, que propiciaria a ambos um centro de gravitação que acentuaria o existencial, favorecendo a passagem de uma fé intelectual para uma fé pessoal, bem como sugere o documento de Aparecida (2007), quando acentua a experiência pessoal de Jesus Cristo como chave para o discipulado e para a ação missionária tanto da Igreja como de cada discípulo missionário (citar Aparecida ).

Talvez a melhor forma de concluir este momento seja recordar as afirmações que o apóstolo Paulo faz no Hino à Caridade, como se encontra em 1Cor 13: a caridade ou o amor - a ágape - é paciente (v. 4), benigna, não é invejosa nem vaidosa, não se ensoberbece, não faz nada de inconveniente (v.5), não é interesseira, não se encoleriza, não guarda rancor, não se alegra com a iniqüidade (v. 6), regozija-se com a verdade, tudo suporta, crê, espera e desculpa (v. 7). E, por isso, não acabará nunca, ou seja, será eterna.

${ }^{15}$ K. RANHER, vol. VIII, 551-579. 


\title{
Resumo
}

O presente artigo analisa as fontes do amor a partir da Encíclica de Bento XVI, Deus caritas est (2007). O texto parte da conceituação bíblica da palavra amor, para, em seguida, abordar o amor de acordo com o ensinamento de Jesus, onde se destaca o mandamento da nova lei, a "regra de ouro" e a nova mentalidade daí decorrente, por parte do seguidor do Mestre Jesus Cristo. Por fim, é desenvolvida uma investigação teológica sobre o amor, onde sobressai a essência do amor, segundo o amor de Deus por nós; a unidade entre o amor a Deus e o amor ao próximo; a Igreja entendida como a comunidade de amor e a relação entre a fé e a esperança.

\begin{abstract}
This article analyses the fountains of love in the view of the encyclical letter Deus caritas est of Benedict XVI. The text starts from the biblical concept of the word love and immediately deals with Jesus' teaching where is emphasized the commandment of the new law, the "golden rule" and the new mentality resulting from them on the followers side of Jesus Christ.

At the end there is developed a theological investigation on the love, where the essence of love stands out, according God's love for the sake of us; the unity between the love to God and to the close friends; the Church seen as a community of love and the relation between faith and hope.
\end{abstract}

Geraldo Luiz Borges Hackmann

Doutor em Teologia pela Pontifícia Universidade Católica do Rio Grande do Sul

\section{Bibliografia}

BENTO XVI, Deus caritas est.

KLOPPENBURG, B. Ágape. O amor cristão. São Paulo: Loyola, 1998.

MEUFFELS, O. Theologie der Liebe in postmoderner Zeit. Würzburg: Echter, 2001.

O'COLLINS, G. Amore. LATOURELLE, R. e FISICHELLA, R. Dizionario di Teologia Fondamentale. Assisi: Citadella Editrice, 1990, p. 17-20.

PESCH, O. Amor. EICHER, P. Diccionario de conceptos teológicos. Barcelona: Herder, 1989 , p. 35-50. 
QUELL, G. e STAUFFER, E. Agapán. G. KITTEL e G. FRIEDRICH, Grande Lessico del Nuovo Testamento. Brescia: Paideia, 1965, vol. 1, col. 57-146.

RAHNER, K. Amor. ID, Sacramentum Mundi, vol 1, Barcelona: Herder, 1976, col. 114-115.

RAHNER, K.; RATZINGER, J.; CHRISTMANN, H. M.; HEINEN, W.; HOFMANN, K. Liebe. BUCHBERGER, M. Lexikon für theologie und Kirche. Freiburg: Herder, 1961, vol. 6, col. 1031-1043.

WARNACH, W. Amor. FRIES, H. Dicionário de Teologia. Conceitos fundamentais da Teologia atual. São Paulo: Loyola, 1970, p. 66-90. 